Technological University Dublin ARROW@TU Dublin

\title{
Stakeholder Engagement and the Future of Irish Public-Private Partnerships
}

\author{
Gail Sheppard \\ Technological University Dublin, gail.sheppard@tudublin.ie \\ Matthias Beck \\ University College Cork
}

Follow this and additional works at: https://arrow.tudublin.ie/buschacart

Part of the Accounting Commons

\section{Recommended Citation}

Sheppard, G. \& Beck, M. (2020)Stakeholder Engagement and the Future of Irish Public-Private Partnerships, International Review of Administrative Sciences,0(0) 1-19 DOI:10.1177/

0020852320971692

This Article is brought to you for free and open access by the School of Accounting and Finance at ARROW@TU Dublin. It has been accepted for inclusion in Articles by an authorized administrator of ARROW@TU Dublin. For more information, please contact arrow.admin@tudublin.ie, aisling.coyne@tudublin.ie, gerard.connolly@tudublin.ie.

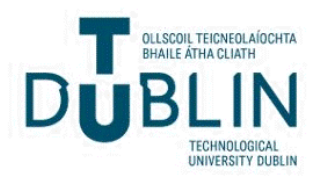




\title{
Gail Sheppard (D)
}

Technological University Dublin, Ireland

\section{Matthias Beck}

University College Cork, Ireland

\begin{abstract}
Building on recent works that stress the importance of stakeholder engagement in partnerships, we propose a novel benchmarking framework for the evaluation of public-private partnerships. This framework describes mutuality and the preservation of organisational identity as the ideal characteristics of partnerships because they, in turn, encourage stakeholder support for public-private partnerships. Applying this framework to infrastructure public-private partnerships in Ireland, we note that mutual accountability has been weakened following the financial crisis. Meanwhile, consultation with clients such as key public-private partnership stakeholders, which would help articulate organisational identities, remains patchy across the education, justice and health public-private partnership that we investigate. Nonetheless, there are sectoral differences. In education, consultation centres on school principals while ignoring teaching staff and trade unions. In justice, attention is focused primarily on judges. Similarly, in health sector public-private partnerships, there is a strong focus on clinicians. Overall, private sector-driven consultation efforts are primarily pragmatic, with a focus on preventing delays and the dissatisfaction of key clients who could prevent future projects from materialising. We suggest that the combination of this calculated approach to consultation, together with the delegation of public-private partnership contracting to an arm's-length government agency, is likely to promote a similar depoliticisation of Irish public-private partnerships as has been observed in other countries.
\end{abstract}

\section{Corresponding author:}

Gail Sheppard, Department of Accountancy, Finance and Professional Studies, TU Dublin, Tallaght, Dublin 24, Ireland.

Email: gail.sheppard@tudublin.ie 
We argue that the potentially harmful stakeholder disengagement that this might encourage can be addressed through a concerted set of measures focusing on improved transparency of decision-making, as well as frameworks that mandate client and public consultation.

\section{Points for practitioners}

Research has highlighted the importance of mutual accountability and the preservation of organisational identity in ensuring that public-private partnerships attract public participation and receive public approval. We investigate public-private partnerships in education, justice and health in Ireland, a country that is widely considered an exemplary public-private partnership practitioner. We observe that consultation by private sector public-private partnership participants with client organisations in these sectors is largely motivated by a desire to prevent hold-ups and secure future business rather than seeking to engage with a broad range of users and stakeholders. Together with the existing lack of evidence of benefits from public-private partnerships, this situation is likely to lead to dissatisfaction with the policy. Indeed, political parties critical of public-private partnerships have been able to significantly increase their share of the vote in a recent national election. Our conclusion is that such dissatisfaction is avoidable if the Irish government improves transparency around public-private partnership decision-making while strengthening requirements for public and client consultation.

\section{Keywords}

accountability, mutuality, public-private partnership, stakeholders, sustainability

\section{Introduction}

The use of public-private partnerships (PPPs) to procure infrastructure and services has evolved to encompass many set-ups, making a definition difficult (Akintoye et al., 2015). PPPs are commonly understood as long-term contractual arrangements between governments and private partners (Hodge and Greve, 2018). PPP generally refers to a range of public-private collaborations, and we use the term 'PPP' for projects that include what were known as private finance initiatives (PFIs) in the UK.

PPPs were launched in Ireland in 1998. The first projects were in education, followed by roads and, more recently, justice and primary care. Why Ireland introduced PPP is unclear (Hearne, 2009). Privatisation policies in Ireland had been driven by pragmatism and initially centred on restructuring state-owned enterprises (Palcic and Reeves, 2004). Minister for Finance McCreevy, who introduced PPP, wanted to replicate UK-style new public management reforms and saw PPP as a way of doing so (Sheppard and Beck, 2016). PPPs were also expected by advisory bodies to bring efficiency gains (NESC, 1999). Over time, these 
justifications became less relevant as PPP use became obligatory following the global financial crisis (Sheppard and Beck, 2016). PPPs were a means to create jobs, stimulate the economy and keep capital expenditure off the balance sheet (Sheppard, 2019). By that time, Ireland had evolved from relying on UK experience to learning from past Irish projects, thus supporting the creation of an Irish pattern of PPP procurement (Sheppard, 2019). With 28 PPP bundles in operations or procurement (Department of Public Expenditure and Reform, 2020) and a total PPP procurement bill of well over €9 billion (Department of Public Expenditure and Reform, 2018), Ireland is now a well-established European PPP user. For example, Ireland's Social Housing Bundle I and II were considered a 'noteworthy transaction' by the European PPP Expertise Centre (EPEC, 2020).

Meanwhile, PPP research moved from measuring success on the basis of value for money to more theoretically informed approaches (Hodge and Greve, 2018), which emphasise stakeholder support and engagement (Foo et al., 2011). Contemporary research into PPP stakeholders views them as prime sources of organisational legitimacy and sustainability (Collins et al., 2005), with sustainability in this context being a predictor of success (Joost et al., 2009). Our work identifies mutuality and organisational identity as prerequisites for, and results of, stakeholder engagement (Brinkerhoff and Brinkerhoff, 2011), and thereby complements models that have investigated accountability comprehensively from a governance perspective (Demirag and Khadaroo, 2009). Utilising a framework that is grounded in these works, our research asks whether stakeholder engagement is one of the weak areas of Ireland's PPP landscape. If so, does this create an environment that allows some partners and stakeholder interests to dominate projects? If the resulting consequence is a lack of stakeholder salience that could adversely affect PPP sustainability, how can this be avoided?

Our article is structured as follows. First, we review contemporary research on the importance of stakeholders in PPP and introduce our conceptual framework. Next, we describe the methodology. Our analysis section first draws on the theme of mutuality and mutual accountability and then examines issues of organisational identity in relation to PPPs in the education, justice and healthcare areas. The conclusion summarises lessons for Ireland and other countries.

\section{Stakeholder engagement in the context of PPP}

In partnerships, different parties bring 'commitment and competence to the table' (Brinkerhoff and Brinkerhoff, 2011: 3), thereby creating collaborations where synergies can evolve. As partnerships, PPPs benefit from strong stakeholder engagement, which helps ensure transparent and sustainable processes (Reeves, 2013a). Stakeholder engagement describes how managers engage with, rather than manage, stakeholders (Collins et al., 2005). The legitimacy and sustainability of an organisation frequently depend on the engagement of managers with stakeholders (Collins et al., 2005). Popular characterisations of stakeholders offered by Freeman (1984), Kearins and Oliver (2006) and Burke and Demirag (2017) 
have thus evolved to highlight their central contribution to the sustainability of organisations, stressing the risks that arise when they underestimate the importance of stakeholder engagement (Collins et al., 2005).

PPP processes are prone to shortcomings (Reeves, 2013a), and these have been particularly pronounced in the UK. Accordingly, Asenova and Beck (2010) document how UK PFI policy failed to involve stakeholders while neglecting local democratic accountability. While the UK's 2018 decision to terminate PPP use for future infrastructure projects has many roots, the dissatisfaction of stakeholders played a major role (Hellowell et al., 2019). Reeves (2013a), reflecting on 12 years of Irish PPP, argues that stakeholder participation is insufficiently developed to secure long-term sustainability.

Collins et al. (2005) theorise that meaningful stakeholder engagement is the conduit from weak sustainability to strong sustainability. Early involvement of stakeholders in dialogue can be the springboard for sustainable organisational design (Collins and Kearins, 2007). The more involved stakeholders are in decisions affecting them, the more likely they are to support projects (Foo et al., 2011), thus creating legitimacy-enhancing dialogues (Devin and Lane, 2014).

However, even where engagement with stakeholders is real, the self-interest of different parties can damage partnerships, the functioning of which is based on additional conditions. Brinkerhoff and Brinkerhoff (2011: 3) examine 'mutuality' and 'organisational identity' as key conditions for functioning partnerships. Mutuality encompasses shared objectives, participation in decision-making, and mutual accountability and transparency (Brinkerhoff, 2002), with mutual accountability being one of the key factors underpinning mutuality. Organisational identity refers to the creation and maintenance of what makes an organisation distinctive. Regarding this factor, Brinkerhoff (2002) argues that by adhering to its core mission, an organisation achieves long-term success, both on its own and within a partnership. Mutuality and organisational identity support stakeholder engagement, while their absence discourages and prevents it.

Participation in decision-making is imperative in stakeholder engagement. Major public policies need support from stakeholders (Riege and Lindsay, 2006). Stakeholder involvement can determine key outcomes of a project (El-Gohary et al., 2006). Research suggests that PPPs are more likely to gain legitimacy where sponsoring governments are supported by stakeholders (Mahalingam, 2011) and where consultation is mandated (Carmin et al., 2003).

Who stakeholders are and how they are perceived can vary among governments (Riege and Lindsay, 2006). Some stakeholders are seen as a risk while others are seen as legitimate and important (Riege and Lindsay, 2006). Citizens or citizenusers, who are sometimes referred to as 'downward stakeholders' (Cordery and Sim, 2018: 5), can suffer from a lack of accountability or 'democracy deficits' in PPP (Shaoul et al., 2012: 214). Although government accountability should lie with citizens (Frederickson et al., 2015), in PPPs, the private sector has major influence in infrastructure decisions, without inherent 'democratic accountability' for those decisions (Mörth, 2007: 601). This lack of PPP accountability to citizens 
(Frederickson et al., 2015) compounds a depoliticisation of PPP, where responsibility is shifted away from elected politicians to specialist agencies (Willems and Van Dooren, 2016). A government partnering with a private company can result in less public accountability but greater trust between partners because normal bureaucratic public sector accounting procedures can be bypassed (Frederickson et al., 2015). This implies that accountability to the public requires efforts if the legitimacy of PPPs is to be maintained (Forrer et al., 2010). Transparency is essential for stakeholder engagement because stakeholders expect it to shape policy development (Riege and Lindsay, 2006). Transparency in PPPs comes through communication, knowledge dissemination (Matos-Castaño et al., 2012: 5), regulation and oversight (Opara, 2014).

If an outcome of a partnership is mutuality and there is equal salience between partners, then stakeholders can be treated equally and there should be shared objectives, participation in decision-making, and mutual accountability and transparency. In such contexts, the level to which organisational identities characterise a partnership mirrors the levels of parity among stakeholders. Organisational identity, as defined by Brinkerhoff (2002), borrows from stakeholder salience theory, which classifies stakeholders as those who possess 'power and urgency' - the controlling partner - and those who possess 'legitimacy' (Mitchell et al., 1997: 870) the beneficiaries. The beneficiaries are the stakeholders or citizens who gain from a PPP, and there is an implied expectation that the organisation will provide value for them (Brinkerhoff, 2002).

Some researchers have argued that, at times, stakeholder engagement is merely a gesture to signal inclusion (Carmin et al., 2003). Apart from deliberate efforts to limit stakeholder engagement to a token act, obstacles arise where stakeholders possess differing capabilities that will affect their ability to participate (Riege and Lindsay, 2006). Some stakeholder groups will be more dominant than others as they exhibit 'power and legitimacy' (Cordery and Sim, 2018: 3). In such complex stakeholder environments, it becomes difficult to ensure equality in stakeholder participation (Riege and Lindsay, 2006).

Brinkerhoff (2002) uses Mitchell et al.'s (1997) stakeholder salience theory which classifies stakeholders as 'definitive', 'dependent', 'demanding' and 'nonstakeholders' - to argue that partnerships necessitate an expanded view of stakeholder rights. Traditionally, definitive stakeholders are seen as possessing three attributes, that is, legitimacy, urgency and power; dependent stakeholders lack power but have urgent legitimate claims; while demanding stakeholders have 'urgent claims but neither power nor legitimacy' (Mitchell et al., 1997: 875). While there is typically no consultation with this latter stakeholder group, this can be problematic for partnerships. Similarly, non-stakeholders cannot necessarily be ignored in PPPs.

Based on research by Collins et al. (2005) and Brinkerhoff and Brinkerhoff (2011), we propose a framework for benchmarking the sustainability of PPPs from a stakeholder perspective (see Figure 1). In line with Brinkerhoff and Brinkerhoff (2011), we suggest that the ideal partnership is characterised by 


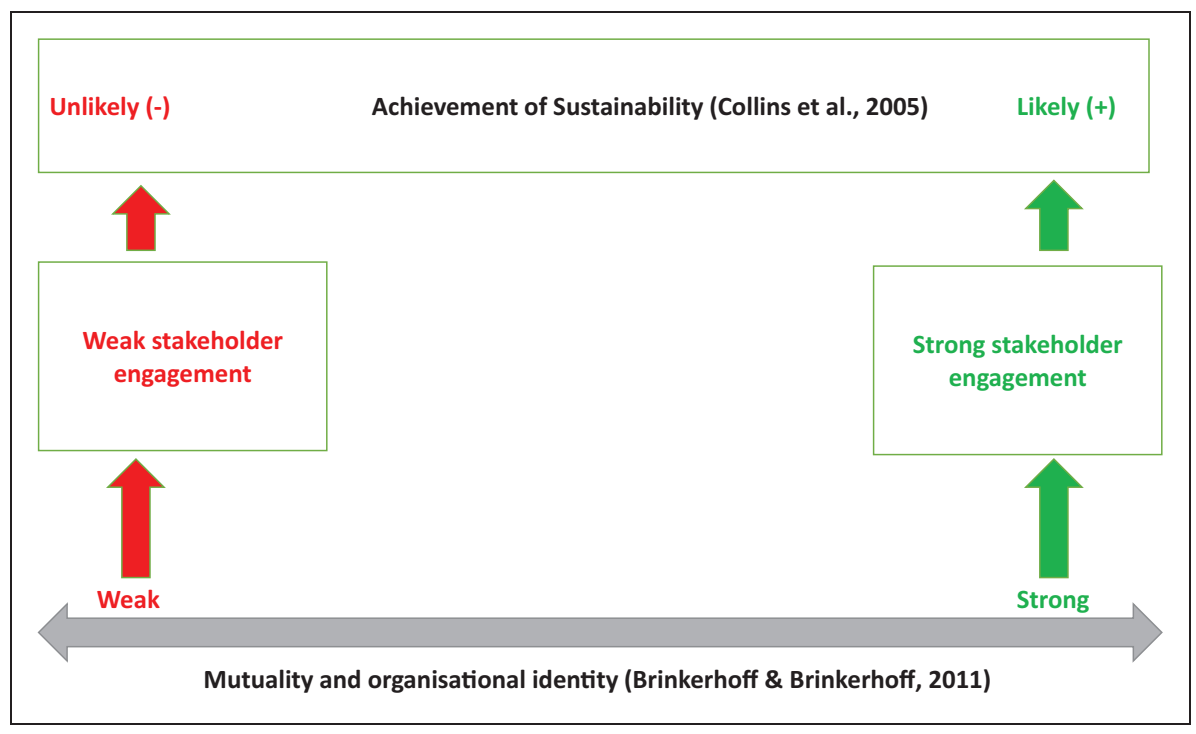

Figure I. Factors contributing to, or hindering, PPP sustainability.

mutuality and respect for organisational identities, which, in turn, encourage and support stakeholder engagement. We recognise that broad and robust stakeholder engagement will contribute to PPP sustainability, and that examining these factors helps gauge the long-term sustainability of a PPP programme in states such as Ireland that are committed to this form of procurement. Figure 1 depicts links between mutuality/mutual accountability, organisational identity, levels of stakeholder engagement and PPP sustainability.

\section{Methodology}

Our research draws on 26 semi-structured interviews with expert representatives from the Irish public, private and civic sectors, all of whom were involved in projects in one or more of the areas of PPP activity investigated here, namely, education, justice and health. Three interviews were conducted between 2013 and 2016, and 24 between 2016 and 2017 (one was discounted). Interviews lasted 60 to 90 minutes and usually took place at the interviewees' offices. Key themes included mutuality, mutual accountability and identity.

The research used a case-study approach in line with Merriam's (1998) model for single phenomenon description - the case being Irish PPP policy. While Irish PPPs were treated as a single phenomenon, it must be kept in mind that they evolved in three stages: Stage 1 pilot projects were procured between 1999 and 2002; Stage 2 projects were procured before the financial crisis between 2002 and 
2008, and include most of Ireland's PPPs; and Stage 3 post-financial crisis projects were procured from 2012 onward.

Interview transcripts, policy documents such as government department documents and literature were brought into NVivo, a qualitative data analysis software, and we used thematic analysis (Braun and Clark, 2006) to examine the semantic and latent levels of meaning of these data. Quotes selected for the study show, at the semantic level, what the interviewees said and help, at the latent level, to interpret the deeper meaning of this.

The literature provides various categorisations of stakeholders. Jooste et al. (2009: 9) refer to stakeholders as 'key constituents' and classify them into three groups: public sector, private sector and civic sector. We include under 'public sector' all governmental organisations; under 'private sector' private companies directly involved in PPP projects; and under 'civic sector' users of the assets, such as local residents, taxpayers and civic organisations.

Interviewees identified specific stakeholder types that were involved in the relevant PPP activities. Table 1 lists these stakeholder types by PPP activity and by broad group (following Jooste et al., 2009).

\section{Analysis}

This section applies an expanded version of the Brinkerhoff and Brinkerhoff (2011) framework, outlined in Figure 1, to the evaluation of Irish PPP to answer our research questions. We focus on how project participants perceive PPPs and how they feel other stakeholders are served. We focus first on the theme of mutuality/ mutual accountability and then on the theme of organisational identity.

Table I. Stakeholder types by PPP activity.

\begin{tabular}{lll}
\hline Education PPPs & Justice PPPs & Health PPPs \\
\hline $\begin{array}{l}\text { Grangegorman Development } \\
\text { Agency }\end{array}$ & $\begin{array}{c}\text { Public sector stakeholders } \\
\text { Judges }\end{array}$ & Clinical staff \\
$\begin{array}{l}\text { Teachers } \\
\text { School principals }\end{array}$ & Office of Public Works (OPW) & \\
$\begin{array}{l}\text { Bidders: construction } \\
\text { companies, banks and equity } \\
\text { investors, and their advisers }\end{array}$ & $\begin{array}{c}\text { Pidders: construction } \\
\text { companies, banks and equity } \\
\text { investors, and their advisers }\end{array}$ & $\begin{array}{c}\text { Bidders: construction } \\
\text { companies, banks and } \\
\text { equity investors, and } \\
\text { their advisers }\end{array}$ \\
$\begin{array}{l}\text { Community groups } \\
\text { Trade unions }\end{array}$ & Civic sector stakeholders & Community groups \\
\hline
\end{tabular}




\section{Mutuality and mutual accountability}

The Irish PPP Advisory Group, comprising business and construction industry interests, trade unions, and governmental groups engaged in PPP, recognised the importance of social partnership and consultation in a $2001^{1}$ publication. Stakeholder guidelines were issued by the Irish Trade Union Federation in $2005{ }^{2}$ emphasising the role of social partnership and stakeholder consultation for PPP success (Joost et al., 2009). Research, however, noted that local residents had no input in a mixed-tenure housing and urban regeneration PPP proposed by Dublin City Council in 2004 (Reeves, 2013a), and in 2011, the Irish Business and Employers' Confederation (IBEC, 2011) argued that greater engagement from stakeholders was needed. A decline of stakeholder consultation, they observed, had occurred during the financial crisis, which saw the cancellation of 24 PPPs (Reeves, 2013b).

Against this background, a majority of our interviewees doubted that there was ongoing mutuality in the PPPs they participated in. They highlighted a lack of independent scrutiny after the initial operation of the asset, which contrasted with the earlier project phases, when private sector PPP participants had to prepare reports for the state PPP agency. As one private sector interviewee said: 'We've probably come off lightly in the amount of scrutiny we get from the public sector.' Interviewees, however, differed in their views on prevailing levels of mutual accountability. Some believed that the paperwork triggering the unitary payments established good accountability. A public sector interviewee thought that the oversight of day-to-day PPP operations by the public sector helped create mutual accountability: 'There's a lot more analysis done, a lot more data...testing that's done on a monthly basis... on most projects.' A private sector interviewee agreed, believing that self-reporting was built on trust between the sectors, which was part of a broader commitment to mutual accountability: "we have to do a monthly report for the authority ... it has to ... [be] very transparent and ... it isn't a wink, wink, nudge, nudge situation'.

Regarding the specific measure of helpdesks, a private sector interviewee explained that this was not overseen by the public sector, but that compliance was a matter of mutual accountability: 'if we don't do something, we have to say we haven't done it, so it's part of your obligation... it has to be very transparent'. Some interviewees also believed mutual accountability to be strengthened by process auditors or independent auditors overseeing the initial operation of the asset. Other interviewees thought that local benchmarking exercises contributed to this as they were carried out to assess service payments. A private sector interviewee noted that during a benchmarking exercise, an external expert was engaged to ensure mutual accountability:

we're responsible for conducting a benchmarking exercise... we would have to go about that in a particular way to ensure that it was transparent... the only way to benchmark effectively is to get somebody independent to do it... otherwise, you'd only have your own data. 
Against this, there were a number of interviewees, mostly from the public sector, who felt that Irish PPP suffered from a lack of mutual accountability, especially in the pre-procurement stage. One public sector interviewee stated bluntly:

whether it goes PPP or goes traditional procurement in the first place is probably where there isn't any transparency at all ... that whole benchmarking thing is a bit of a ... black hole from those of us looking in from the outside. Maybe it needs to remain like that, I don't know.

One possible reason, mentioned by the same interviewee, was political expediency: 'the lack of transparency is choosing the projects, in terms of what gets picked to be funded, you know, that's... a political decision'. Another public sector interviewee suggested that, especially after the financial crisis, PPP was seen as a means to an end, to a level where more mutual accountability could be a problem if it led to delays: "when people want something like...[a] building, they may say, "Well...look, we want it, just get on with it". Another public sector interviewee felt that current decision-making did not create mutual accountability since neither side knew precisely what the bidding criteria were:

value-for-money testing is done on a project-by-project basis and the minister is supposed to not sign off ... until it is ... proved that it is value for money, but do they do that? I don't know, I doubt if you'll find out.

PPPs are subject to pre-approval value-for-money tests, meant to justify them to stakeholders, but test outcomes are not publicised. One public sector interviewee noted that this had been considered but that concerns with commercial confidentiality had prevented it (Dáil Éireann Committee of Public Accounts, 2012). A senior public sector interviewee involved in PPP decision-making stated that reviews of projects should and could be published without contract details. Similarly, a private sector interviewee cited examples from Canada, where this information was published, to argue that doing this in Ireland would contribute to mutual accountability.

Although value-for-money assessments are given central importance by the Irish government and would be important for demonstrating the benefits, full evaluation of projects has generally not taken place. To make things worse, the robust and consultative decision-making that characterised early Irish PPP projects seems to have been eroded after the financial crisis. Combined with opacity around how decisions to employ PPP are made, this makes it difficult to document mutual benefits with transparent evidence.

\section{Organisational identity}

Our analysis of organisational identity in relation to PPP refers to specific PPP activities because the nature of these activities impacts significantly on the 
expectations of clients with regard to their organisational image and status. Specifically, we survey three areas of PPP activity - education, justice and health services - each of which comes with different organisational expectations and with a different mix of stakeholders.

Education PPPs. Almost all Irish primary schools are funded by the state; however, the majority are owned and managed by religious bodies (Mawhinney, 2007). Denominational schools also play an important role in Ireland's secondary school system, where they cater for nearly $60 \%$ of the total student intake, while vocational and tertiary education is generally state-financed, with a variety of ownership structures (Darmody and Smyth, 2013). For all three levels of education, this means that providers have strong organisational identities that extend to typically unionised teaching staff, who expect near-lifetime employment (Clarke and Killeavy, 2012). Education PPPs collectively have formed the most significant PPP sector in Ireland (Sheppard, 2019).

Our interviewees indicated that consultation was mixed in primary and secondary education projects. Involvement varied across stakeholder type and PPP phase. One teachers' union interviewee spoke about the lack of consultation with unions: 'There was no consultation with teachers' unions around ... the commencement of building new schools under the PPP...the unions aren't at the table.' On the unions' reaction to the introduction of PPP, they also stated: 'Apart from a few dissident voices, there wasn't a critical opposition ... because it was seen as a way of getting things done. It was seen as a way of actually mobilising resources.' This apparent indifference seems to be shared. An interviewee from another teachers' union said that it was not that they did not have a policy on PPP; it was just that he could not find it.

Interviewees also noted that the lack of consultation initially caused concerns among school principals: 'At the beginning, there was ... concern about that and a clash of roles and ... they were concerned about roles, role conflict and their legal standing.' Limited consultation with education staff appears to have remained the rule, with a private sector partner commenting: 'It's very limited, the engagement with them ... we met them a couple of times.' What little consultation there was occurred mostly in later phase PPPs and then centred on principals rather than teachers. In early (Stage 1 and 2) PPPs, there was little involvement even of school principals at the construction stage, as a private sector participant noted: '[the large builders] never allowed the head or anybody on to site until it was finished'. This was because 'the authority kept the schools at arm's length from the contractor... because if you give somebody a design, they'll come back with a hundred questions'. Consultation with school principals, however, took place in later (Stage 3) projects: 'That did evolve over time... we would have three monthly meetings with the principal of the school, telling them what was going on ... giving them a tour of the school.'

Consultation at the operational phase was stronger and a private sector interviewee noted that they recognised the importance of engaging with education staff 
when it came to the stage where the Operations \& Maintenance Company (O\&M Co.) was to be involved. However, this also followed a hierarchical pattern. Despite the emphasis on maintaining a relationship with the public sector, this centred on school principals, not teaching or auxiliary staff. Public sector interviewees suggested that PPP learning took place among school principals, who helped each other out when interacting with the private sector partner.

Engagement also took place with local communities affected by the building of PPP schools, particularly at the construction phase. As one private interviewee explained: 'We tell the community about the schools...get people up to speed ... explain the project.' Despite the limited consultation and its hierarchical nature, this interviewee suggested that teachers and principals were not dissatisfied: 'The principal is happy, the teachers are happy, they have... better services, their state-of-the-art buildings ... they are well maintained.'

Overall, consultation in education was patchy and fell below the ideal laid out in guidelines (Department of Finance, 2005). It was weak with teaching staff and trade unions at the construction phase, mixed with school principals at the construction phase, and only became robust with the latter during the operational phase. In so far as the organisational identity of schools was concerned, this was articulated primarily by school principals at the later stage of the procurement process, with little room for such concerns in the early stages of project planning and design. As a consequence, incentives for stakeholder engagement were limited, with projects being seen as a welcome but externally imposed novelty.

Justice PPPs. In the UK, the justice sector has been a major procurer of PPPs (Mizell, 2018). In Ireland, there have been two main justice PPPs: the Criminal Courts of Justice (CCJ), a Stage 2 PPP signed in 2007; and a Stage 3 courts bundle contract in December 2015. An early review of the CCJ project found that clients were adequately engaged (Mazars, 2012).

While there was consultation in justice projects, this was seen as a complex issue because there were multiple users, as a private sector interviewee noted:

the judges' staff ... defendants ... solicitors, barristers, legal aid, probation service, the prison service, Gardaí, some of the other support groups, the victims groups ... you get about 10 or 12 major stakeholders, a lot of whom are on the opposite sides.

This interviewee was nonetheless adamant that PPP-built facilities were better for users: 'there's a comfort... as to what can be delivered by PPP and when they [clients] see a big swathe of buildings being delivered, they are all happy'. Another private sector interviewee confirmed this: 'I think it's ... of huge benefit to ... the community that it's putting stuff into.'

As far as consultation was concerned, there was again a noticeable hierarchy. Several public and private sector interviewees spoke about judges' needs being met but did not mention other stakeholder groups. One interviewee who worked on the CCJ said judges travelled to the Manchester courts to see how a PFI worked. 
Another spoke of judges' involvement in the design process. There was no mention of meeting the needs of other court staff and users. This partly mirrored the focus of consultation on school principals. However, with judges having significant input into the design stages of these projects, they were able to shape some of organisational identity they sought to have expressed in these PPP projects, which may explain some of their positive feedback for justice buildings.

Health sector PPPs. Engagement with clients was generally strong in Stage 3 health sector projects at the design and construction stage. Our interviews did not cover the operational stage as health sector projects were still under construction. Again, some stakeholders were given more power than others, while PPP consortia found it difficult to meet demands. One private sector interviewee suggested that it could be difficult to decide what was possible: 'I suspect there's that constant tussle between the end user wanting ... to know what it looks like or [that] it doesn't cost much to run.' Meanwhile, there was agreement among private sector interviewees that interaction with clinicians was considerable:

at every stage of the process ... we go ... right down to the level of the clinician to review ... is this going to meet their requirements?... because it has ... a fundamental... impact on the service that you deliver to patients.

Regarding this concern with clinicians' requirements, one interviewee reported that when a clinician wanted a sink installed differently from others, this was allowed.

Despite this focus on clinicians, one private sector interviewee stated that significant consideration was given to patients in PPP design: 'We teamed up with ... a big provider of primary care in the UK who knew how these buildings need to operate and how they are best laid out for patients.' Consultation with local communities also took place, especially where these were affected by a facility, with one private sector interviewee stating:

we recognise that there's a huge value of bringing people in on the inside at the early stages because even if people are not happy, at least if you've had the consultation process, it's a little bit easier to manage than if you don't at all.

A private sector interviewee stated that the 'requirement to take on a certain number of apprentices, trainees', strengthens support from the local community. Mention of consultation with mid-level health sector employees, such as nurses or medical administrators, was notably absent, indicating that engagement in this sector also followed a hierarchical pattern. With pronounced focus on communities and patients in addition to clinicians as core clients, however, there is evidence that recent health sector PPPs were among the most advanced areas when it came to recognising and supporting organisational identities. 


\section{Summary}

In terms of mutual accountability and respect for organisational identity, Irish PPPs appear to have followed a paradoxical trajectory. Mutual accountability at the PPP pre-procurement and procurement stage appears to have declined, with state decision-makers giving less information about the criteria underpinning their choices to industry and the public following the financial crisis, in line with PPP being increasingly seen as a means of facilitating off-balance-sheet investment and employment creation. Meanwhile, PPP practitioners, including those from the private sector, appear to have become more cognisant of the need to engage with clients so as to support client organisational identities. This appears to be particularly pronounced in relation to Stage 3 health sector PPPs, while also being evident in education and justice PPPs. The engagement that underpins this interaction with client organisations is, however, strategic - bordering the opportunistic - in the sense that individuals and groups with veto power are consulted during stages when the exercise of this power could jeopardise project execution (see Table 2).

In terms of classical stakeholder salience theory this reflects a focus on definitive stakeholders, who, as a consequence, can exert disproportionate influence on project design and operations in comparison to other stakeholder groups (see Table 3). At the time of writing, only data on operational PPPs in education were available. Future research could investigate stakeholder consultation for operational PPPs in other sectors.

Our analysis mapped different types of Irish PPP stakeholders to Mitchell et al.'s (1997) framework. We found that the stakeholders who exhibited the most power at the design and construction stages were local communities, judges and clinicians, these being stakeholders who could prevent PPP implementation. As PPPs became operational, school principals became more powerful. This suggests that the role of definitive stakeholder is attributed to relatively few PPP participants in a selective manner during the PPP cycle, leaving out significant numbers of 'non-definitive' stakeholders.

Table 2. Consultation intensity by stakeholder type, stage of PPP cycle and activity.

\begin{tabular}{|c|c|c|c|}
\hline & Weak & Mixed & Strong \\
\hline $\begin{array}{l}\text { Design and } \\
\text { construction } \\
\text { stages }\end{array}$ & $\begin{array}{l}\text { Education } \\
\text { (teaching staff) } \\
\text { Education } \\
\quad \text { (trade unions) }\end{array}$ & $\begin{array}{l}\text { Education } \\
\qquad \text { (school principals) }\end{array}$ & $\begin{array}{l}\text { Education } \\
\text { (local communities) } \\
\text { Justice (judges) } \\
\text { Health sector } \\
\text { (clinicians and local } \\
\text { communities) }\end{array}$ \\
\hline Operational stage & & & $\begin{array}{l}\text { Education (school } \\
\text { principals) }\end{array}$ \\
\hline
\end{tabular}




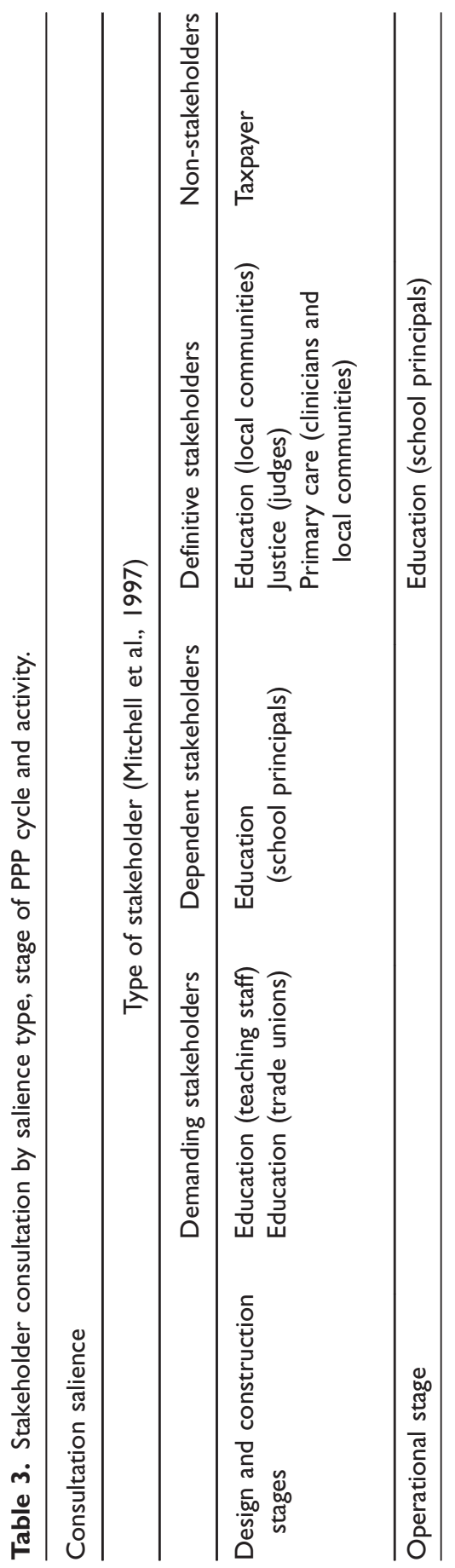




\section{Conclusion}

Ireland is considered a European PPP leader, and the COVID-19 pandemic is likely to increase PPP use here and elsewhere. Notwithstanding limitations that arise from our focus on stakeholder involvement as compared to operational factors, our analysis suggests that the Irish approach to PPP procurement is in need of improvement. This is based on the development of our theoretical framework (see Figure 1), grounded in the prior research of Collins et al. (2005) and Brinkerhoff and Brinkerhoff (2011). Having applied this framework to mutuality and mutual accountability in Irish PPP, we see little clarity with regard to government PPP decisions. This has the potential of reducing incentives among private bidders to forward competitive bids and, perhaps more importantly, limits public recognition of the benefits of PPP beyond the availability of a facility.

Previous analyses have suggested that there is 'downward accountability' in partnership arrangements (Shaoul et al., 2012: 214), where citizen interests are largely ignored, and some authors have suggested that the categories of those included among 'downward stakeholders' are growing (Cordery and Sim, 2018: 5). While our analysis confirms this overall picture, we suggest that there is selectiveness in client engagement that is project-specific and strategic to a level where a deceptive impression of local accountability and technical propriety might be created. We find these strategic concerns to be the main factors in the differential treatment of clients, albeit that contractual aspects will possess greater relevance in other countries (Abdullah and Khadaroo, 2020). Consultation and the respect for organisational identity that it creates centre on those who could potentially derail a project or prevent future projects from materialising. If this interaction still supports the identity of an organisation and its members, it is probably more by accident than by planning, which, in turn, makes broad and long-term engagement of stakeholders unlikely.

One of the consequences of this neglect of stakeholder engagement and its underpinning factors of mutuality and organisational identity is a depoliticisation of PPP. This can be described as a process where the standard approaches of public accountability are no longer fully applied to PPPs while other mechanisms of national, regional and local democratic governance are also partly suspended. Institutionally, this depoliticisation is often associated with arm's-length national procurement or contracting agencies, which are not subject to the same level of scrutiny as government ministries. Many aspects of this type of depoliticisation

apply to Irish PPP today. As mentioned earlier, the criteria for PPP procurement are largely unknown, value-for-money tests remain unpublished and post-project evaluation rarely takes place. Institutionally, the National Development Finance Agency acts as the PPP procurement body, frequently presiding over decisions for which the details are withheld from the public on account of commercial confidentiality (Reeves, 2015).

Skelcher (2005; see also Frederickson et al., 2015) was among the first to suggest that the public-private negotiation process underpinning PPPs made for a likely 
reduction in public and political accountability. More recent research by Willems et al. (2017) argues that some factors inherent in PPP policy militate against democratic governance. These include a widespread reliance on consultants, the need for profitability and complex contracting. They argue this contributes to 'political distrust and disappointment because political decision makers tend to use PPPs as miracle solutions for the delivery of public infrastructure without bearing the longterm budgetary consequences of their own decisions' (Willems et al., 2017: 1).

While we would share many of these concerns, we would contend that these developments are not inevitable. Granted, a recent election in Ireland has seen parties critical of PPP gain votes (Sinn Féin, 2019). However, while PPP in Ireland is running a risk of public dissatisfaction, there is no inevitability of that risk materialising if transparency and accountability are strengthened.

PPP will gain in importance and there is a need to create frameworks where: PPP procurement processes maximise mutual benefits for participating state agencies, private sector partners and the public; benefits and costs are openly and transparently communicated to the public; and organisational identities of stakeholders are respected and enhanced. A requisite measure for this would be the creation of a national framework for PPP consultation similar to that of the 'Programme for prosperity and fairness' (Department of the Taoiseach, 2000), which used social partnership to agree mechanisms to procure and deliver PPP. Then, and only then, will PPP exhibit mutuality and respect organisational identity.

\section{Declaration of conflicting interests}

The authors declared no potential conflicts of interest with respect to the research, authorship and/or publication of this article.

\section{Funding}

The authors received no financial support for the research, authorship, and/or publication of this article.

\section{Notes}

1. Framework for Public Private Partnerships, Working Together for Quality Public Service, Department of Finance, November 2001.

2. Department of Finance (2005) Stakeholder consultation for employees and their representatives: Central guidelines for state authorities undertaking PPP projects. Available at: https://ppp.gov.ie/key-documents/guidance/central-guidance/ (accessed 30 June 2018).

\section{ORCID iD}

Gail Sheppard (D) https://orcid.org/0000-0003-1404-6977 


\section{References}

Abdullah A and Khadaroo I (2020) The trust-control nexus in PPP contracts. Journal of Accounting and Public Policy. Epub ahead of print 27 July 2020. DOI: 10.1016/j. jaccpubpol.2020.106768

Akintoye A, Beck M and Kumaraswamy M (2015) Public Private Partnerships. Abingdon: Routledge.

Asenova D and Beck M (2010) Crucial silences. Critical Perspectives on Accounting 21(1): $1-13$.

Braun V and Clark V (2006) Using thematic analysis in psychology. Qualitative Research in Psychology 3(2): 77-101.

Brinkerhoff DW and Brinkerhoff JM (2011) Public-private partnerships: Perspectives on purposes, publicness, and good governance. Public Administration and Development 31(1): 2-14.

Brinkerhoff JM (2002) Government-nonprofit partnership. Public Administration and Development 22(1): 19-30.

Burke R and Demirag I (2017) Risk transfer and stakeholder relationships in public private partnerships. Accounting Forum 41(1): 28-43.

Carmin J, Darnall N and Mil-Homens J (2003) Stakeholder involvement in the design of US voluntary environmental programs. Policy Studies Journal 31(4): 527-543.

Clarke M and Killeavy M (2012) Charting teacher education policy in the Republic of Ireland with particular reference to the impact of economic recession. Educational Research 54(2): 125-136.

Collins E and Kearins K (2007) Exposing students to the potential and risks of stakeholder engagement when teaching sustainability. Journal of Management Education 31(4): 521-540.

Collins E, Kearins K and Roper J (2005) The risks in relying on stakeholder engagement for the achievement of sustainability. Electronic Journal of Radical Organisation Theory 9(1): 81 .

Cordery CJ and Sim D (2018) Dominant stakeholders, activity and accountability discharge in the CSO sector. Financial Accountability and Management 34(1): 77-96.

Dáil Éireann Committee of Public Accounts (2012). Available at: https://data.oireachtas.ie/ ie/oireachtas/debateRecord/committee_of_public_accounts/2012-12-06/debate/mul@/ main.pdf (accessed 22 May 2018).

Darmody M and Smyth E (2013) Governance and Funding of Voluntary Secondary Schools in Ireland. ESRI Research Series, 32. Dublin: ESRI.

Demirag I and Khadaroo I (2009) Accountability and value for money. Journal of Management and Governance 15(2): 271-296.

Department of Finance (2005) Stakeholder consultation for employees and their representatives. Available at: https://ppp.gov.ie/key-documents/guidance/central-guidance/ (accessed 30 June 2018).

Department of Public Expenditure and Reform (2018) Report of the Inter-Departmental/ Agency Group on PPPs. Available at: file://C:/Users/Gail/Documents/Research/Policy $\%$ 20documents/ROI\%20Policy\%20Documents\%20and\%20NDFA/Report-of-theExpert-Group-on-PPPs-July-2018.pdf (accessed 4 May 2020).

Department of Public Expenditure and Reform (2020) Projects. Available at: https://ppp. gov.ie/ppp-projects/ (accessed 4 May 2020). 
Department of the Taoiseach (2000) Programme for prosperity and fairness. Available at: https://www.taoiseach.gov.ie/upload/publications/310.pdf (accessed 16 June 2018).

Devin BL and Lane AB (2014) Communicating engagement in corporate social responsibility. Journal of Public Relations Research 26(5): 436-454.

El-Gohary NM, Osman H and El-Diraby TE (2006) Stakeholder management for public private partnerships. International Journal of Project Management 24(7): 595-604.

EPEC (European PPP Expertise Centre) (2020) Market Update Review of the European PPP Market in 2019. Luxembourg: EPEC.

Foo LM, Asenova D, Bailey S, et al. (2011) Stakeholder engagement and compliance culture. Public Management Review 13(5): 707-729.

Forrer J, Kee JE, Newcomer KE, et al. (2010) Public-private partnerships and the public accountability question. Public Administration Review 70(3): 475-484.

Frederickson HG, Smith KB, Larimer CW, et al. (2015) The Public Administration Theory Primer. Boulder, CO: Westview Press.

Freeman RE (1984) Strategic Management: A Stakeholder Approach. Boston, MA: Pitman.

Hearne R (2009) Origins, Development and Outcomes of Public Private Partnerships in Ireland, Working Paper 09-07. Dublin: Combat Poverty Agency.

Hellowell M, Stafford A and Stapleton P (2019) Austerity and hospitals in deficit: Is PPP termination the answer? Abacus 55(3): 535-556.

Hodge GA and Greve C (2018) Contemporary public-private partnership. Financial Accountability and Management 34(1): 3-16.

Irish Business and Employers' Confederation (2011) What Next for Infrastructure? Dublin: IBEC.

Jooste SF, Levitt RE and Scott WR (2009) Capacity, legitimacy, and interest: Toward a framework for PPP program success. Lead Conference, South Lake Tahoe, CA, US.

Kearins K and Oliver G (2006) Inclusiveness incorporated: Characterisation of stakeholders and partners in annual reports. 20th ANZAM Conference, Yeppoon, Australia.

Mahalingam A (2011) Creating an Enabling Environment for PPPs. Sricity, India: IFMR Research.

Matos-Castaño J, Dewulf G and Mahalingam A (2012) The complex interplay between the institutional context and PPP project outcomes. Engineering Project Organizations Conference, Rheden, Netherlands.

Mawhinney A (2007) Freedom of religion in the Irish primary school system. Legal Studies 27(3): 379-403.

Mazars (2012) Post Project Review Dublin Criminal Courts Complex. Dublin: Mazars.

Merriam SB (1998) Qualitative Research and Case Study Applications in Education. San Francisco, CA: Jossey-Bass.

Mitchell RK, Agle BR and Wood DJ (1997) Toward a theory of stakeholder identification and salience. Academy of Management Review 22(4): 853-886.

Mizell L (2018) Public-Private Partnerships at the Subnational Level of Government, OECD Multilevel Governance Studies. Paris: OECD.

Mörth U (2007) Public and private partnerships as dilemmas between efficiency and democratic accountability: The case of Galileo. European Integration 29(5): 601-617.

NESC (National Economic and Social Council) (1999) Opportunities, Challenges and Capacities for Choice. Dublin: NESC.

Opara M (2014) Public private partnerships in Alberta's transportation infrastructure. Unpublished PhD thesis, Athabasca University, Canada. 
Palcic D and Reeves E (2004) An economic analysis of privatisation in Ireland, 1991-2003, Journal of the Statistical and Social Inquiry Society of Ireland XXIV: 1-27.

Reeves E (2013a) The not so good, the bad and the ugly. Local Government Studies 39(3): 375-395.

Reeves E (2013b) Public private partnerships in Ireland: A review of the experience. Available at: https://www.nerinstitute.net/events/2013/public-private-partnerships-ire land-review-experience (accessed 5 November 2020).

Reeves E (2015) A review of the PPP experience in Ireland. Journal of Comparative Policy Analysis 17(5): 467-480.

Riege A and Lindsay N (2006) Knowledge management in the public sector. Journal of Knowledge Management 10(3): 24-39.

Shaoul J, Stafford A and Stapleton P (2012) Accountability and corporate governance of public private partnerships. Critical Perspectives on Accounting 23(3): 213-229.

Sheppard G (2019) The sustainability of public-private partnership in Ireland. Unpublished $\mathrm{PhD}$ thesis, University College Cork, Ireland.

Sheppard G and Beck M (2016) The evolution of public-private partnership in Ireland. International Review of Administrative Sciences 84(3): 579-595.

Sinn Féin (2019). Social Housing PPPs almost six times more expensive than standard social housing. Available at: https://www.sinnfein.ie/contents/53356 (accessed 14 May 2020).

Skelcher C (2005) Public-private partnerships and hybridity. In: Ferlie E, Lynn Jr LE and Pollit C (eds), The Oxford Handbook of Public Management. Oxford Handbooks Online.

Willems T and Van Dooren W (2016) (De)Politicization dynamics in public-private partnerships (PPPs). Public Management Review 18(2): 199-220.

Willems T, Van Dooren W and van den Hurk M (2017) PPP policy, depoliticisation, and anti-politics. Partecipazione e conflitto 10(2): 448-471.

Gail Sheppard, PhD, MSc, ACMA, is a Lecturer in accounting at Technological University Dublin. Her ongoing research interests include value for money in, and the performance of, public resource allocation. Prior to this, she held posts as a management accountant in industry.

Matthias Beck holds a Chair in Management at the Cork University Business School, University College Cork, Ireland. His research interests are in the areas of risk, health management, PPPs and public sector management. 